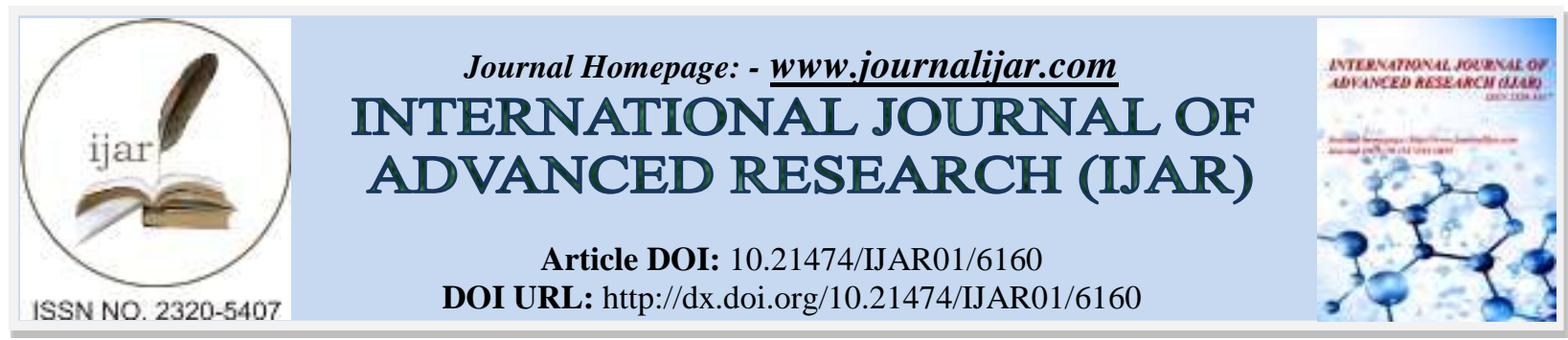

RESEARCH ARTICLE

\title{
OCTREOTIDE INDUCED HYPERSENSITIVITY REACTION: A RARE CASE REPORT.
}

\section{Banerjee Priyotosh ${ }^{1}$, Kumar Tarun ${ }^{2}$, Swer Phrang Kupar ${ }^{3}$, P. Shyamasakhi Devi ${ }^{4}$ and A. Pfuzia ${ }^{5}$.}

1. Post graduate Junior Resident, Regional Institute of Medical Sciences, Imphal.

2. Post graduate Junior Resident, Regional Institute of Medical Sciences, Imphal.

3. Post graduate Junior Resident, Regional Institute of Medical Sciences, Imphal.

4. Associate Professor, Regional Institute of Medical Sciences, Imphal.

5. Senior Resident, Regional Institute of Medical Sciences, Imphal.

\section{Manuscript Info}

(.........................

Manuscript History

Received: 24 October 2017

Final Accepted: 26 November 2017

Published: December 2017

\section{Abstract}

Octreotide is an octapeptide analogue of Somatostatin used to supress Growth hormone activity and treatment of acromegaly, carcinoid and other hormone secreting tumours. Also in management of variceal bleeding secondary to portal hypertension and chylothorax, post cardiac surgery. Commonly nausea, diarrhoea, gall stones occur as adverse effect. Rarely hypersensitivity reaction occurs, which may become life threatening. Here we are describing a case of 42 year male patient was brought complained of vomiting of blood and developed hypersensitivity reaction after administration of inj. Octreotide. To our knowledge it is the first case occurring in our institute and also a rare occurrence. Prompt management was done and alternative treatment was initiated.

Copy Right, IJAR, 2017,. All rights reserved.

\section{Introduction:-}

Octreotide is an octapeptide analogue of somatostatin used to suppress growth hormone (GH) activity ${ }^{1}$. Acting on somatostatin receptors $\mathrm{SST}_{2}, \mathrm{SST}_{5}$, it blocks the activity of $\mathrm{GH}^{2}$. In spite of having plasma half life of 90 minutes, its action persists for around 12 hours. ${ }^{3}$ It has been used in the treatment of acromegaly, carcinoid and other hormone secreting tumours ${ }^{3}$. It has been widely used in the treatment of oesophageal varices secondary to portal hypertension to control acute bleeding ${ }^{4}$ on the basis that it reduces portal venous pressure. Apart from this, octreotide has effect in treating chylothorax occurring in patients after cardiac surgery ${ }^{5}$. Common adverse effects are abdominal pain, nausea, steatorrhoea, diarrhoea, and gall stones ${ }^{1}$. Rarely hypersensitivity reactions have been reported as side effect ${ }^{6}$. Here we are presenting a case report of a 42 years old male patient who developed hypersensitivity reaction after administration of $100 \mu \mathrm{g}$ inj. of octreotide deep subcutaneously.

Case report: A 42 years old male was brought to the casualty RIMS, Imphal, Manipur on 23/09/2016 with the complain of vomiting of blood once on the same day. The amount of the vomitus was scanty (about $50 \mathrm{ml}$ ), cherry red in colour. No foul smell was noticed and it was mixed with recently ingested food. At the time of presentation, the patient gave history of chronic alcohol intake for the past 7 years. The bleeding was suggestive of upper gastrointestinal bleed. On examination, patient was conscious, well oriented to time, place and person. No pallor, jaundice, dehydration, lymphadenopathy, oedema or ascites was noted during physical examination. No tenderness was noted on abdominal examination, nor any organomegaly. His blood report showed elevated SGOT, SGPT, ALP, and GGT. Diagnosis was made as oesophageal varices, secondary to alcoholic liver disease. The patient was 
admitted in medicine ward and treated with Cytostatin (octreotide acetate) $100 \mu \mathrm{g}$ deep subcutaneous injection, along with his regular oral antianxiety drugs and vitamin $\mathrm{K}$ injection. Within $30 \mathrm{~min}$ of administration of octreotide, the patient developed erythematous pin point skin rashes with itching and burning sensation all over the body. On examination patient was restless, BP- 100/70 mm Hg, pulse- 80/min. Systemic examination was normal. On examination of rashes they were found to be reddish and pin point type, suggestive of hypersensitivity reaction. Patient was immediately given symptomatic management like i.v. fluids, corticosteroids \& antihistaminic drugs. The condition of the patient improved drastically. It has been reported to the Pharmacovigilance Centre, RIMS Imphal. On the next day, drug re- challenge was done with the same dose under supervision of doctors with all precautionary measures. It showed similar pattern of reaction. So it was withdrawn finally. The patient was then discharged with the advice to avoid alcohol and to continue his routine medication.
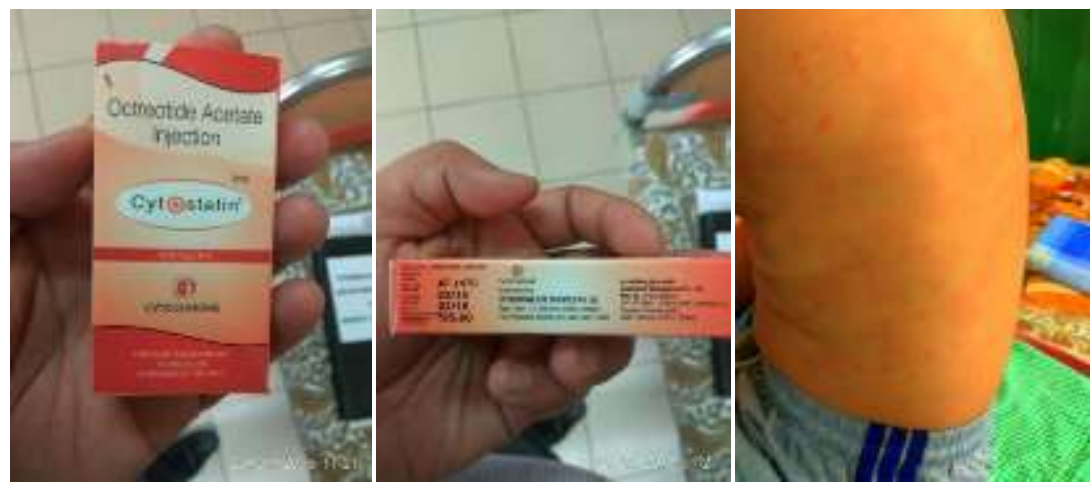

Pictures showing the reported drug with its batch number, manufacturing and expiry dates and the hypersensitivity reaction showing pin point red spots over the body of the patient.

\section{Discussion:-}

Hypersensitivity is a set of undesirable reactions produced by the normal immune system including allergies and autoimmunity. It can occur from various products such as foods, drugs or other environmental constituents. Here in this case, the hypersensitivity reaction involving mainly the skin occurred due to the administration of deep subcutaneous injection of octreotide.

Although urticaria, allergy/hypersensitivity reactions and anaphylaxis have been noted as possible adverse reactions, there is lack of data showing a causal relationship between octreotide and hypersensitivity reactions and there is no information on management when continued use of this medication is essential. ${ }^{[7,8]}$ Hypersensitivity reaction to octreotide occurs rarely and it require urgent management.

\section{Conclusion:-}

Octreotide is a popular medicine in patients with portal hypertension presenting with variceal bleeding. Hypersensitivity and anaphylaxis though rare but has been reported and it needs urgent assistance. Immediate desensitization should be considered if treatment with octreotide has to be continued and no other alternative option is available. 


\section{References:-}

1. Tripathi KD. Essentials of Medical Pharmacology. 7th ed. New Delhi: Jaypee Brothers Medical Publishers (P) Ltd; 2013. p. 237-8

2. Parker KL, Schimmer BP. Introduction to endocrinology: The Hypothalamic-Pituitary axis, In: Bruton LL, Chabner BA, Knollmann BC, editors. The Pharmacological Basis of Therapeutics. $12^{\text {th }}$ ed. New York: The McGraw Hill Companies;2011: p. 1112-4

3. Rang HP, Dale MM, Ritter JM, Flower RJ, Henderson G. Pharmacology. $7^{\text {th }}$ ed. Spain;Elsevier;2012. p. 394-5

4. Bacon BR. Cirrhosis and its Complications, In: Longo DL, Kasper DL, Jameson JL, Fauci AS, Hauser SL, Loscalzo J. Priciples of Internal Medicine. $18^{\text {th }}$ ed. New York: The Mc-Graw Hill Companies;2011. P. 2592606

5. Pessoti CFX, Jatene IB, Buononato PEU, Elias PF, Pinto ACD, Kok MFJ. Use of octreotide in the treatment of chylothorax and chyloperitonium. Arquivos Brasileiros De Cardiologia[Internet]. 2011 Aug [cited 2017 Oct 30]; $\quad$ 97(2): $\quad$ Available $\quad$ from: $\quad$ http://www.scielo.br/scielo.php?pid=S0066782X2011001100017\&script=sci_arttext\&tlng=en

6. Azkur D, Yoldas T, Toyran M, Kokabas CN. A paediatric case of anaphylaxis due to octreotide. Asian Pacific Journal of Allergy and Immunology.2011;29:361-3

7. Growth hormone granulation pattern and somatostatin receptor subtype $2 \mathrm{~A}$ correlate with postoperative somatostatin receptor ligand response in acromegaly: a large single center experience. [cited 2017 Oct 30] Available from: https://link.springer.com/article/10.1007/s11102-012-0400-1

8. Octreotide 100 micrograms $/ 1 \mathrm{ml}$ Solution for Injection. [cited 2017 Oct 30] Available from: http:/www.medicine.i.e/medicine/17292/SPC/octreotide+100+micrograms+1. 